\title{
Electrochemical performance of zirconia/ graphene oxide nanocomposites cathode designed for high power density supercapacitor
}

\author{
Harish Mudila', Sweta Rana² and M. G. H. Zaidi ${ }^{*}$
}

\begin{abstract}
Background: Carbon-based metal oxide nanocomposites are always been the prime material for study in the field of energy storage due to their rich abundance, low toxicity, high surface area, electrical conductivity and diverse oxidation states.

Methods: In this direction, novel zirconia/graphene oxide $\left(\mathrm{ZrO}_{2} / \mathrm{GO}\right)$ nanocomposites are fabricated on the surface of 316 stainless steel for studying their specific capacitance and power performance. $\mathrm{ZrO}_{2}$ and $\mathrm{GO}$ in varying mass ratio $(1: 1,1: 2$, and 2:1) were used to fabricate the electroactive material. The physical interaction between the two was determined by Fourier transform-infrared, X-ray diffraction and scanning electron microscopy. TG-DTA-DG informs about the exhibited thermal property by the variants. The cyclic voltammetry was done to study the specific capacitance of the electroactive materials with reference to $\mathrm{Ag} / \mathrm{AgCl}$ at scan rate $(\mathrm{V} / \mathrm{s})$ ranging $0.15-0.001$ in 1.0 M KOH. The specific capacitance of $\mathrm{ZrO}_{2}$ was found to be $17.13 \mathrm{Fg}^{-1}$ at $0.001 \mathrm{Vs}^{-1}$. The representative (nanocomposite) NC-II shows the maximum specific capacitance of $299.26 \mathrm{Fg}^{-1}$ at similar rate of scan with power density of $59.40 \mathrm{~W} / \mathrm{kg}$.

Conclusion: The nanocomposites show comparable level of charge-discharge behavior with long-term cycleability, suggesting that fabricated $\mathrm{ZrO}_{2} / \mathrm{GO}$ nanocomposite electrodes are promising candidate for the high-performance energy storage devices.
\end{abstract}

Keywords: Zirconium oxide, Graphene oxide, Specific capacitance, Cyclic voltammetry

\section{Background}

Metal oxides depending upon their structural, geometries, and electronic structure play a very significant role in areas of chemistry, physics, biology and material sciences (Marcos and Rodriguez 2007; Graves 2014). Technical applications of these metal oxides involve the fabrication of electronic circuits, sensors, optical devices, piezoelectric devices, fuel cells, corrosion less surfaces coatings and catalysis, etc. (Sahu and Rao 2000; Wang et al. 2010; Ye et al. 2013; Lee et al. 2010; Mugniery

\footnotetext{
* Correspondence: mghzaidi@gmail.com

${ }^{2}$ Department of Chemistry, G. B. Pant University of Agriculture \& Technology, Pantnagar, Uttarakhand 263145, India

Full list of author information is available at the end of the article
}

et al. 1999). The proliferation of personal electronics and commercialization of electric and hybrid electric vehicles have popularized the needs for rechargeable and portable power sources and thus had increase the exploration of metal oxide in this direction. Supercapacitors in 21st era had attracted intense research interest as an auxiliary and clean source of power and energy. Due to their low molecular weight and their favorable electrochemical and solid-state properties, first and second row transition metal oxides seem to be especially attractive as cathode materials in electrochemical energy storage systems. In this perspective, many transition metal oxides alone and with nanostructured carboneous filler had got special attention due to 
their low price, rich abundance, low toxicity, and diverse oxidation states (Wu et al. 2012; Lee et al. 2011; Zhao et al. 2013; Mai et al. 2014; Chen et al. 2012). In this exploration, a large number of metal oxide-graphene oxide combinations are synthesized to study the supercapacitive behavior (Wu et al. 2012; Lee et al. 2011; Wu et al. 2012). The electronic properties of the metal oxide are effected by particle size of material, the quantum size or confinement effects are produced in nanostructured materials which essentially arise from the presence of discrete, atom-like electronic states (Marcos and Rodriguez 2007), and also nanosized material is observed to have small band gap in its lattice. Thus, metal oxide nanoparticles can exhibit unique physical and chemical properties due to their limited size and a high density of corner or edge surface sites. Apart from this, metal oxide materials exhibit ionic or mixed ionic/electronic conductivity and are influenced by the nanostructure of the material (Tuller 2000).

Nano-phase zirconia $\left(\mathrm{ZrO}_{2}\right)$ is a widely used heterogeneous catalyst and is an n-type semiconductor with band-gap energy of $5.0 \mathrm{eV}$ (Pouretedal and Hosseini 2010). Zirconium oxide $\left(\mathrm{ZrO}_{2}\right)$ is a smart material being studied for various applications such as oxygen sensor, solid state electrolytes for fuel cell, and gradient refractive index lenses due to its excellent mechanical, thermal, optical, and electrical characteristics (Pouretedal and Hosseini 2010; Liu et al. 2013). Studies on depositing $\mathrm{ZrO}_{2}$ onto carbon nanotubes (CNTs) (Lu et al. 2008; Shan and Gao 2005; Song et al. 2009; Guo et al. 2009), graphene (Wu et al. 2012, Liu et al. 2013), etc. for fuel cells and transistors as advanced gate dielectrics (Javey et al. 2002) had placed it in the row of promising candidate for high-power energy storage material.

Since its discovery, graphene oxide and graphene have become the key star in research associated with energy production and energy storage because of their $\mathrm{sp}^{2}$ carbon nanoform arrangement in 2D network with remarkable electronic, mechanical properties, and high morphological anisotropy (Stoller et al. 2008; Kim et al. 2009; Yoo et al. 2011; Tian et al. 2012, Yee et al. 2011). Graphene oxide $(\mathrm{GO})$ provided large accessible surface area for effective transportation of ions onto the material surface, thus accomplishing high electric-doublelayer capacitance in aqueous electrolytes (Yang et al. 2011). Nanostructured metal oxides can effectually prevent the Van der Waals-induced agglomeration of GO, resulting large accessible electrochemical active surface area for energy storage. Size and morphology affect the performance of metal oxides used as electrode materials. Designing nanostructured semiconducting metal oxide materials with graphene family has been the key to success in developing large-specific capacitive energy storage devices.
Studies based on I/V characteristics reveal very low $\mathrm{C}_{S}$ and stability for $\mathrm{ZrO}_{2}$ and other metal oxides (Ye et al. 2013; He et al. 2013). While GO is a well-known material for its implication in the field of energy production and storage, this accounts of higher $\mathrm{C}_{\mathrm{S}}$ of $\mathrm{GO}$ over $\mathrm{ZrO}_{2}$ which prompted to investigate the effect of $\mathrm{GO}$ concentration on the $\mathrm{C}_{\mathrm{S}}$ of $\mathrm{ZrO}_{2}$ in the respective nanocomposites (NCs). In the present study, three variant of $\mathrm{ZrO}_{2} / \mathrm{GO}$ NCs were synthesized with molar concentrations of $\mathrm{ZrO}_{2}$ and $\mathrm{GO}$ (1:1, $1: 2$, and 2:1). GO dispersed in methanol was sonicated into a solution comprising of tetraethyl ammonium bromide (TEAB). To this, requisite amounts of $\mathrm{ZrO}_{2}$ were supplied and the contents were further sonicated. The resulting suspension was then washed repeatedly with methanol and distilled water (20:80) to obtain nanosized $\mathrm{ZrO}_{2} / \mathrm{GO}$ composites which shows high level of specific capacitance, energy, and power density along with good capacitive retention of $98.6 \%$. Along with this, workers had also found out that specific capacitance of $\mathrm{ZrO}_{2} / \mathrm{GO}$ is comparable to $\mathrm{ZrO}_{2}$ /graphene nanocomposite which was found to be $10 \mathrm{~F} / \mathrm{g}$ at $0.05 \mathrm{~V} / \mathrm{s}$ by Liu et al. (2013).

\section{Methods}

\section{Starting materials}

$\mathrm{ZrO}_{2}\left(\mathrm{M}_{\mathrm{W}}\right.$ 123.22, $99.5 \%$, APS $\left.45 \mathrm{~nm}\right)$ was purchased from Sisco Research Laboratories Pvt. Ltd., India. Polysulphone (PSO, $\mathrm{M}_{\mathrm{n}}, 26,000, \rho=1.24 \mathrm{~g} / \mathrm{cm}^{3}$ ) and chlorosulfonic acid (bp., $152 \pm 1{ }^{\circ} \mathrm{C} / 755 \mathrm{mmHg}, \rho=1.753 \mathrm{~g} / \mathrm{cm}^{3}$ at $25^{\circ} \mathrm{C}$ ) were procured from Aldrich Chemical Comp. Inc., USA. Tetraethyl ammonium bromide (TEAB, $\mathrm{M}_{\mathrm{W}} 210.17$, $99 \%$ was procured from Molychem, and graphite $(98.0 \%$, surface area $500 \mu \mathrm{m})$ was purchased from Otto Chemicka-Biochemica reagents, India. All other chemicals and solvents were purchased from s.d. fine Chemical, India. All the chemicals and solvents were used without further purifications. The commercially available 316stainless steel (SS) was used as substrate for the preparation of electrode.

\section{Preparation of $\mathrm{ZrO}_{2} / \mathrm{GO} \mathrm{NCs}$}

Three variant of $\mathrm{ZrO}_{2} / \mathrm{GO}$ NCs were synthesized with molar concentrations of $\mathrm{ZrO}_{2}$ and GO (Table 1). The requisite amount of $\mathrm{GO}$ was dispersed in methanol $(20 \mathrm{~mL}, 99.9 \%)$ and was sonicated into a solution comprising of TEAB $(50 \mathrm{mg})$ for $3 \mathrm{hr}$ at $40 \pm 1{ }^{\circ} \mathrm{C}$. To this, requisite amounts of $\mathrm{ZrO}_{2}$ were supplied and the contents were further sonicated for additional $3 \mathrm{hr}$ at $40 \pm$

Table 1 Synthetic molar ratio of constituents

\begin{tabular}{lllc}
\hline S. No. & $\mathrm{NCs}$ & $\mathrm{ZrO}_{2}: \mathrm{GO}$ & Particle size $(\mathrm{nm})$ \\
\hline 1. & $\mathrm{NC}-\mathrm{I}$ & $1: 1$ & 26.63 \\
2. & $\mathrm{NC}-\mathrm{II}$ & $1: 2$ & 27.34 \\
3. & $\mathrm{NC}-\mathrm{III}$ & $2: 1$ & 24.76 \\
\hline
\end{tabular}


$1{ }^{\circ} \mathrm{C}$. The resulting suspension was then washed repeatedly with methanol and distilled water (20:80), which was filtered and dried at $50{ }^{\circ} \mathrm{C} / 400 \mathrm{mmHg}$ over $48 \mathrm{hr}$.

\section{Fabrication of working electrode}

Prior to use, well-finished $1 \mathrm{~cm}^{2} 316$-SS was supplied as substrate and then de-greased with acetone and subjected to surface oxidation at $50 \pm 1{ }^{\circ} \mathrm{C}$ over $1 \mathrm{hr}$ under vacuum. The working electrode materials were prepared by mixing the electroactive material, graphite, and sulphonated polysulphone (SPS) in a mass ratio of 65:10:25. After sonicating the mixtures for $1 \mathrm{~h}$ in $\mathrm{N}$-methylpyrrolidone (NMP), the resulting slurry was pressed on a stainless steel substrate which acts as a current collector. The treated substrate was dried at room temperature for $4 \mathrm{hr}$, followed by $100{ }^{\circ} \mathrm{C} / 400 \mathrm{mmHg}$ for $48 \mathrm{hr}$. The mass of the material deposited on the substrate was determined from the weight difference between the electrode before and after deposition by using a high precision microbalance. This has afforded cathodes with mass thickness of electroactive materials by $1.0 \pm 0.1 \mathrm{mg} / \mathrm{cm}^{2}$ over SS substrate. The electrodes were tested after $24 \mathrm{hr}$ of fabrications.

\section{Result and discussion}

\section{FT-IR spectra}

Fourier transform-infrared (FT-IR) spectra were recorded on Thermo Nicolet FT-IR Spectrophotometer in $\mathrm{KBr}$ in the range $4000-400 \mathrm{~cm}^{-1}$ (Fig. 1a-e). Graphite has

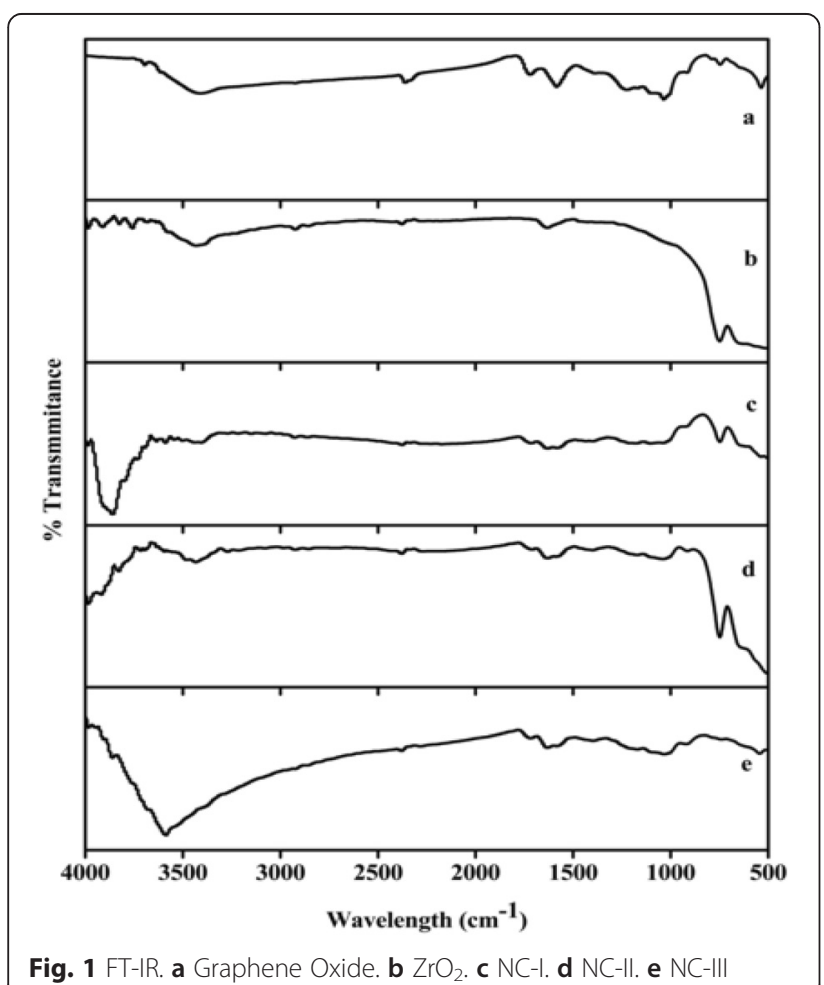

revealed characteristic absorptions $\left(\mathrm{cm}^{-1}\right)$ at $3447(v \mathrm{O}-$ $\mathrm{H})$ and $1628.79(\delta \mathrm{O}-\mathrm{H})$ which attributes to the presence of absorbed moisture (Fig. 1a) and characteristic absorptions at $\sim 3333(v \mathrm{O}-\mathrm{H}), 1723(v \mathrm{COOH}), 1613$ (remaining $\mathrm{sp}^{2}$ character), 1378 ( $v$ COC), 1221.20 (C-O for oxirane), and $1033 \mathrm{~cm}^{-1}(v \mathrm{COH})$ indicates conversion of graphite into GO (Fig. 1b) (Reta et al. 2009). Figure 1c shows characteristic absorptions of $\mathrm{ZrO}_{2}$ particularly at 740 and 500 ( $v$ as $\mathrm{Zr}-\mathrm{O}-\mathrm{O}-\mathrm{Zr}$ and $\mathrm{Zr}-\mathrm{O}$ stretching modes), respectively, which confirms the $\mathrm{ZrO}_{2}$ phase (Sahu and Rao 2000). The absorptions at 3430 and 1630 correspond to the vibration of stretching and deformation of the $\mathrm{O}-\mathrm{H}$ bond due to the absorption of water (Sahu and Rao 2000; Chen et al. 2012). The representative of $\mathrm{ZrO}_{2} / \mathrm{GO}$ nanocomposite, NC-II, illuminates characteristic absorptions 3430-3440 ( $v \mathrm{O}-\mathrm{H}), 1710(v \mathrm{COOH}), 1640(\delta \mathrm{O}-\mathrm{H})$, 1600 (sp $^{2}$ character), 1390 ( $v$ COC), 1190 ( $v$ C-O epoxy), $1040(v \mathrm{COH}), 748(v \mathrm{Zr}-\mathrm{O}-\mathrm{O}-\mathrm{Zr})$, and $503(v \mathrm{Zr}-\mathrm{O})$. The absorption corresponding to $(v \mathrm{COOH})$ shifted to 1710 in NC-II over GO at 1723 . With concentration of $\mathrm{ZrO}_{2}$, a regular decrease in the intensity of absorption corresponding to $v \mathrm{O}-\mathrm{H}$ with simultaneous increase in the intensity of absorption corresponding to $v \mathrm{Zr}-\mathrm{O}-\mathrm{O}-\mathrm{Zr}$ and $v \mathrm{Zr}-\mathrm{O}$, respectively, was observed. Such shift in the absorption of $v \mathrm{COOH}$ from 1723 to 1710 may be assigned to the bonding of $\mathrm{ZrO}_{2}$ with GO. Furthermore, the increase in the intensity of $v \mathrm{Zr}-\mathrm{O}-\mathrm{O}-\mathrm{Zr}$ and $v \mathrm{Zr}-\mathrm{O}$ with simultaneous decrease in $v \mathrm{O}-\mathrm{H}$ in $\mathrm{GO}$ also supports the bonding of $\mathrm{ZrO}_{2}$ with $\mathrm{GO}$ (Fig. 1d).

\section{Microstructure}

The power X-ray diffraction (XRD) spectra of asprepared samples were recorded at room temperature over Rigaku-Geiger flex X-ray diffractometer using $\mathrm{Cu}$ $\mathrm{K}_{\alpha}$ radiation $(\lambda=0.154 \mathrm{~nm})$ in the range of $10^{\circ}-70^{\circ}$ at $30 \mathrm{kV}$ and $15 \mathrm{~mA}$ with step size 0.05 and step time of $19.2 \mathrm{~s}$. The diffraction peaks observed at $2 \theta$ were used to calculate the particle size using Bragg's equation:

$$
d=\frac{n \lambda}{2 \sin \theta}
$$

The XRD spectra of graphite shows the peak corresponding to $2 \theta=26.47^{\circ}(d=3.369)$, reduced to $2 \theta=11.829^{\circ}(d=$ $7.473 \AA$ Á) which indicates the exfoliation of the graphite into GO (Fig. 2a, b); $\mathrm{ZrO}_{2}$ shows several strong peaks located at $2 \theta=28.25^{\circ}(d=3.155 \AA), 31.5^{\circ}, 34.3^{\circ}, 40.95^{\circ}, 50.45^{\circ}$, $55.55^{\circ}, 60^{\circ}$, and $62.9^{\circ}$ indicating their monoclinic nature (Fig. 3a) (Wu et al. 2012; Guo and Ding 2004; Cheng et al. 2011). With increase in concentration of GO, a regular increase in the gallery spacing of $\mathrm{ZrO}_{2}$ in respective NCs has been observed ranging $2 \theta=28.10^{\circ}$ to $27.80^{\circ}(d=3.172$ to $3.205 \AA$ Á) as observed in Fig. 3b-d. 


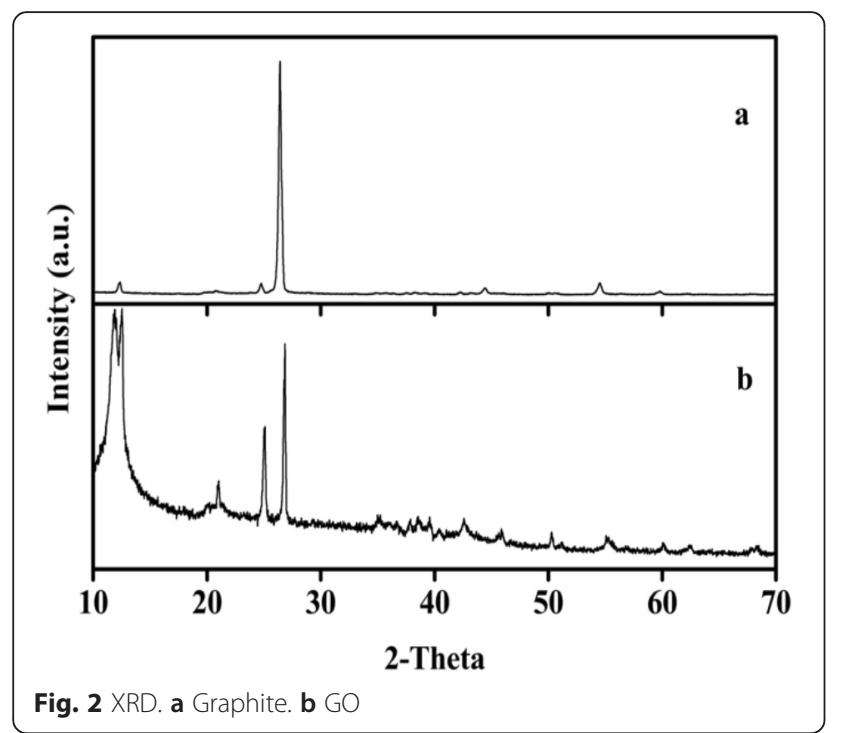

The average particle size (Table 1) of all the samples was examined by using Debye-Scherrer formula:

$$
D=\frac{0.9 \lambda}{\beta \cos \theta}
$$

where " $\lambda$ " is the wave length of X-ray (1.541 $\AA$ ), " $\beta$ " is the FWHM (full width at half maximum), " $\theta$ " is the diffraction angle, and " $\mathrm{D}$ " is the particle diameter size.

\section{XPS studies}

X-ray photoelectron spectroscopy (XPS) was carried out using XPS (VG ESCALAB 2000), using a monochromatic

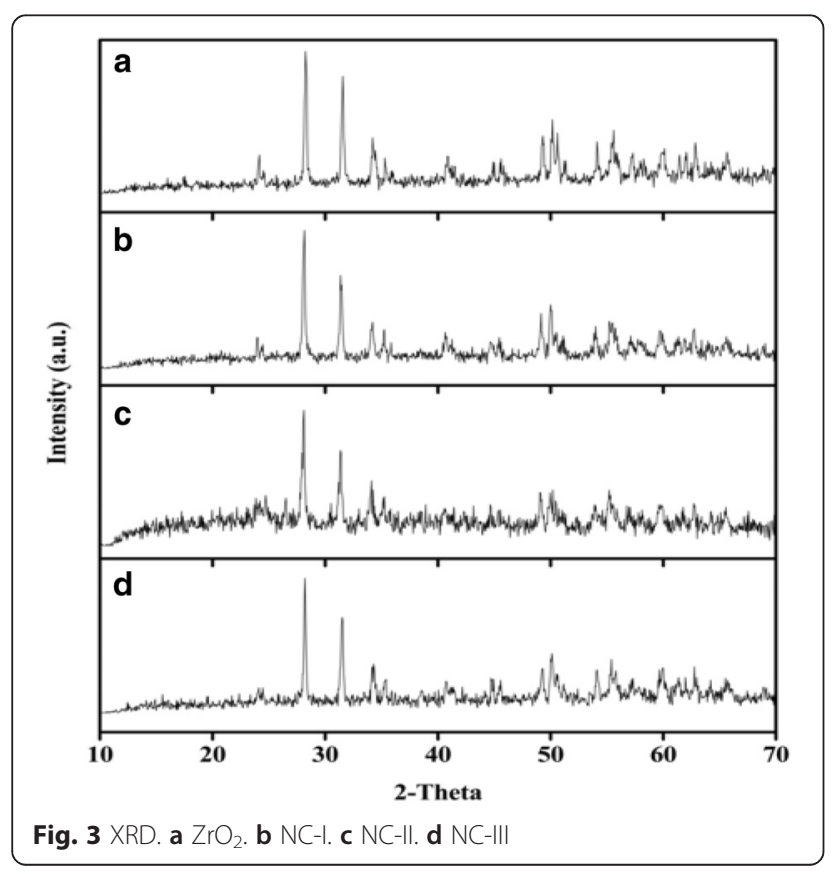

$\mathrm{Al} \mathrm{K \alpha} \mathrm{X-ray} \mathrm{source} \mathrm{(1486.6} \mathrm{eV).} \mathrm{The} \mathrm{XPS} \mathrm{spectrum} \mathrm{of} \mathrm{the}$ NC-II shows the presence of the elements of $\mathrm{ZrO}_{2}$ and GO (Fig. 4). The peak corresponds to the characteristic peaks of $\mathrm{Zr} 3 \mathrm{~d}, \mathrm{C} 1 \mathrm{~s}$, and $\mathrm{O} 1 \mathrm{~s}$ indicating the existence of zirconium, carbon, and oxygen in the sample. The signal for $\mathrm{C} 1 \mathrm{~s}$ obtained at the $\mathrm{C}=\mathrm{C} / \mathrm{C}-\mathrm{C}(283 \mathrm{eV}), \mathrm{C}-\mathrm{O} / \mathrm{C}-\mathrm{O}-$ $\mathrm{C}$ (hydroxyl and epoxy groups, $285.8 \mathrm{eV}$ ), $\mathrm{C}=\mathrm{O}$ (carbonyl groups, $288.2 \mathrm{eV}$ ), and $\mathrm{O}-\mathrm{C}=\mathrm{O}$ (carboxyl groups, $290.0 \mathrm{eV}$ ) indicates the presence of graphene oxide sheets, whereas signals observed at 533.2 corresponds to $\mathrm{ZrO}_{2}$, such as O 1s (Pham et al. 2011, Suchorski et al. 2008).

Morphology of graphene oxide, $\mathrm{ZrO}_{2}$, and $\mathrm{ZrO}_{2} / \mathrm{GO}$ NCs Scanning electron microscopy (SEM) of the treated SS surfaces with $\mathrm{GO}, \mathrm{ZrO}_{2}$, and NCs was recorded on JEOL (JSM-6610 LV) using a primary beam voltage of $5 \mathrm{kV}$ under identical magnifications and scales of 5.5 to 1.0 $\mathrm{KX}$ and $2-10 \mu \mathrm{m}$, respectively. Blending of GO (75 \%, $w / w)$ with SPS has afforded the respective composite material that reveals flaky appearance of GO at $1.0 \mathrm{KX}$, $10 \mu \mathrm{m}$. Further increase in magnification shows a well distribution of flakes of GO in SPS matrix (Fig. 5a-c). A competitive account of SEM images with the $\mathrm{ZrO}_{2}$ $(75 \%, w / w)$ in SPS matrix reveals that on filling grains of $\mathrm{ZrO}_{2}$ into SPS matrix, a fine distribution has been observed on higher magnification (Fig. 5d-f).

The morphological change in the as-grown $\mathrm{ZrO}_{2}$ on GO (NC-II) into SPS matrix indicates the formation of multiphase system created due to component used for preparation of electrode. Such multiphase system has been well distinguished in Fig. $5 \mathrm{~g}-\mathrm{i}$. All the nanocomposites show porous stacking structures of graphene oxide sheets. There is no remarkable dependency of

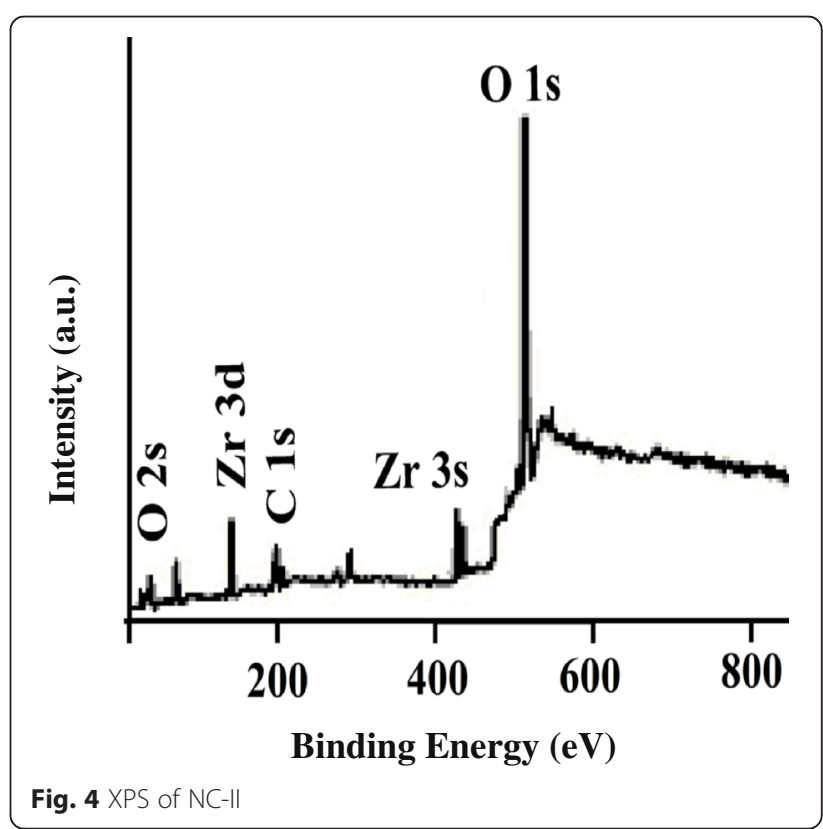




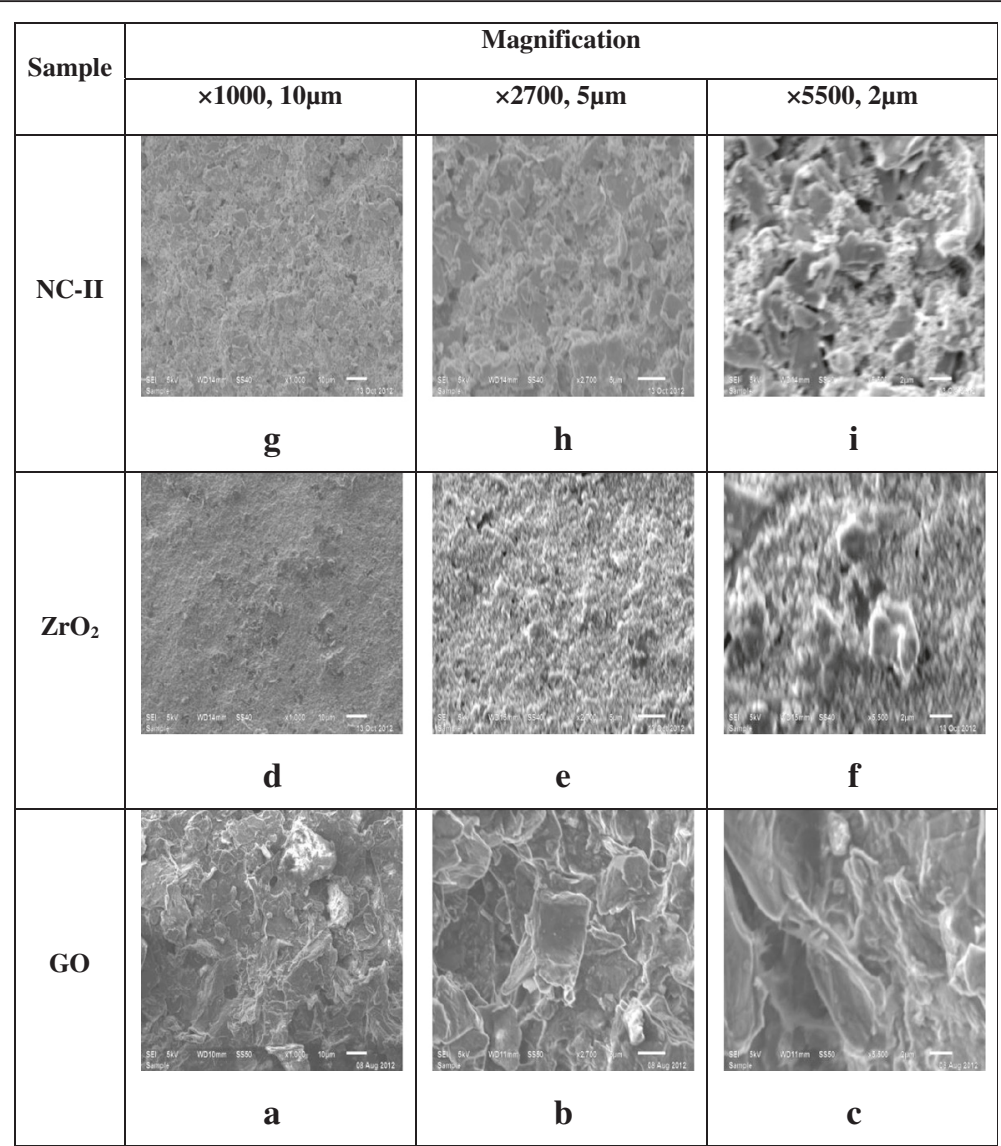

Fig. 5 SEM micrographs of GO (a-c), ZrO (d-f) and NC-II (g-i) at various magnifications

crystal morphology on the mixing ratio of zirconium oxide and graphene oxide, confirming homogeneous distribution of the two. The observed porous morphology of the present nanocomposite is quite different from the nonporous morphology of the pristine $\mathrm{ZrO} 2$ material which may be due to the presence of $\mathrm{GO}$ in the former.

\section{Atomic force microscopy}

Figure 6 shows the AFM images of the $\mathrm{ZrO}_{2}, \mathrm{GO}$, and $\mathrm{ZrO}_{2} / \mathrm{GO}$ (NC-II) film over the substrate at room temperature, the surface of the film was very smooth (confirmed by cyclic voltammetry), and the roughness was only 25,25 , and $12 \mathrm{~nm}$ of RMS (root mean square), respectively. The continuous granular morphology of the $\mathrm{ZrO}_{2} / \mathrm{GO}$ film reveals that the film might be constructed by an amorphous network. The reduced roughness in case of nanocomposite may be attributed to the filling of interstitial site of $\mathrm{ZrO}_{2}$ by GO nanoparticles (Chang and Doong 2005; Vilian et al. 2014).

\section{Thermal analysis}

DTA-DTG-TG data were recorded over EXSTAR TG/ DTA/6300 in air at flow rate of $200 \mathrm{~mL} / \mathrm{min}$ in the temperature ranging 30 to $800{ }^{\circ} \mathrm{C}$ with heating rate of $10{ }^{\circ} \mathrm{C} / \mathrm{min}$. The sample size was in the range of 10.5 to $10.9 \mathrm{mg}$. Two-step decomposition was shown by thermogram of GO (Fig. 7). In the first-step decomposition of GO appeared at $170{ }^{\circ} \mathrm{C}$ leaving wt. residue $87.4 \%$, this has been supported with weak DTA signal of $0 \mathrm{mV}$ at $206{ }^{\circ} \mathrm{C}$ with heat of fusion $216 \mathrm{~mJ} / \mathrm{mg}$ (Fig. 8) and a DTG peak at temperature $204{ }^{\circ} \mathrm{C}$ with range of degradation $0.57 \mathrm{mg} / \mathrm{min}$ (Fig. 9). Prior to this temperature, GO was decomposed leaving residue of $91.2 \%$ at $106{ }^{\circ} \mathrm{C}$. This may be assigned to the loss of moisture $(0.8 \%)$ present in GO. Increase in temperature beyond $170{ }^{\circ} \mathrm{C}$ indicates a rapid weight loss in GO leaving weight residue $74.9 \%$ at $215{ }^{\circ} \mathrm{C}$. Within the range of temperature $170-215{ }^{\circ} \mathrm{C}$, the functionalities over GO created due to oxidation of graphite has been removed, reverting this into graphite (Some et al. 2013). On subsequent heating of GO from $215-432{ }^{\circ} \mathrm{C}$, a steep weight loss has been observed at $432{ }^{\circ} \mathrm{C}$ leaving weight residue $57.2 \%$. This may be assigned due to thermal stability of graphite. The rapid decomposition of graphite was observed at 432 to $486{ }^{\circ} \mathrm{C}$ supported with an intense DTA signal of $1 \mathrm{mV}$ at $499{ }^{\circ} \mathrm{C}$ with heat of decomposition 


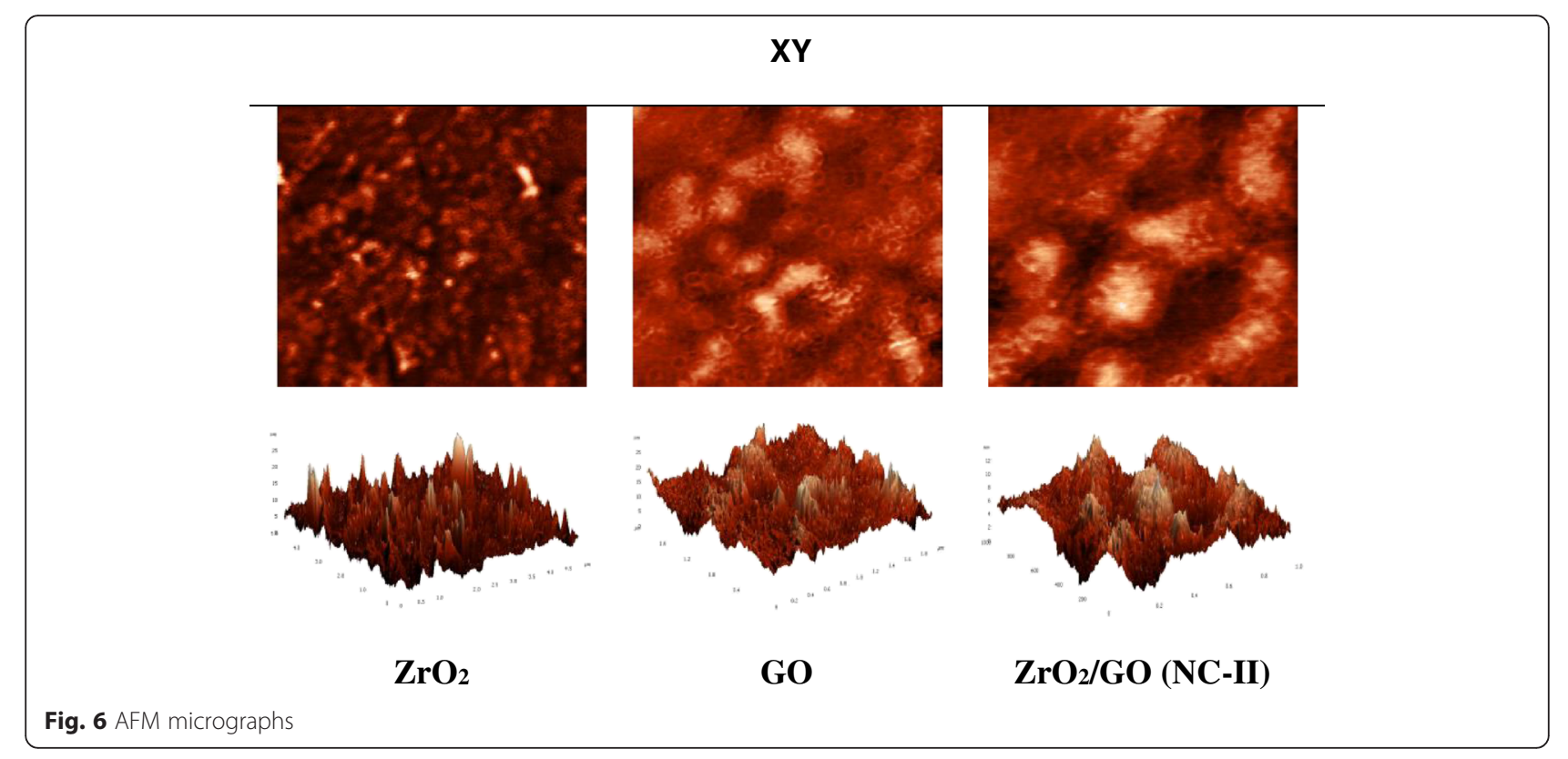

6.24 J/mg. Such decomposition of GO was progressed with rate of decomposition $3.10 \mathrm{mg} / \mathrm{min}$ at $472{ }^{\circ} \mathrm{C}$. Further increase in temperature from $468{ }^{\circ} \mathrm{C}$ has contributed a marginal loss in weight leaving residue $14.6 \%$ at $547{ }^{\circ} \mathrm{C}$. The decomposition of GO was terminated at $818{ }^{\circ} \mathrm{C}$ leaving $13.3 \%$ weight residue due to formation of carbon black.

Thermogram of $\mathrm{ZrO}_{2}$ reveals that it is free from any contamination. $\mathrm{ZrO}_{2}$ shows rapid decomposition up to $700{ }^{\circ} \mathrm{C}$ leaving $98.81 \%$ and was associated with moisture

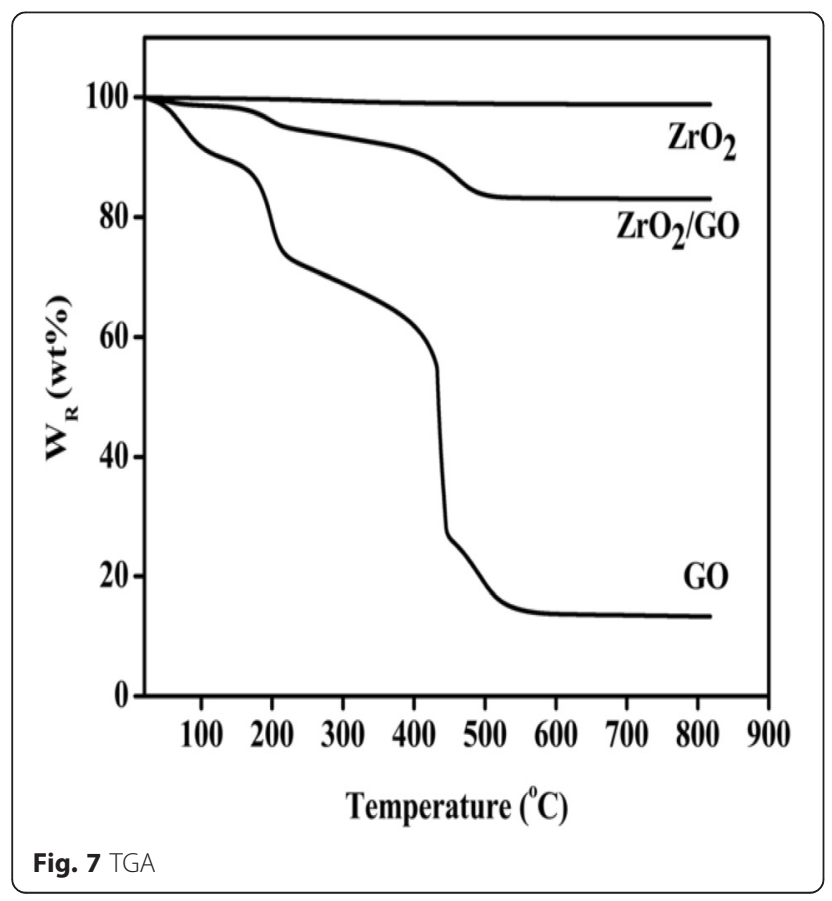

of $0.15 \%$ (Fig. 7). No observed degradation peaks occur in DTA and DTG analysis of $\mathrm{ZrO}_{2}$ proving that the material is quite resistible towards thermal degradation (Figs. 8 and 9, inset).

The NC-III derived from $\mathrm{ZrO}_{2}$ shows two-step decomposition (Fig. 7). The first-step decomposition of NC-III appeared at $152{ }^{\circ} \mathrm{C}$ leaving $98.2 \%$ residue. This was supported with a DTG at $197{ }^{\circ} \mathrm{C}$ with the rate of degradation $84.2 \mu \mathrm{J} / \mathrm{min}$. Before this temperature, a weight loss of $1.27 \%$ at $99.8^{\circ} \mathrm{C}$ may be assigned content of NC. Such removal of moisture of $\mathrm{NC}$ was progressed at the rate of $32 \mu \mathrm{J} / \mathrm{min}$ at $48{ }^{\circ} \mathrm{C}$. Decomposition of $\mathrm{NC}$ was in the

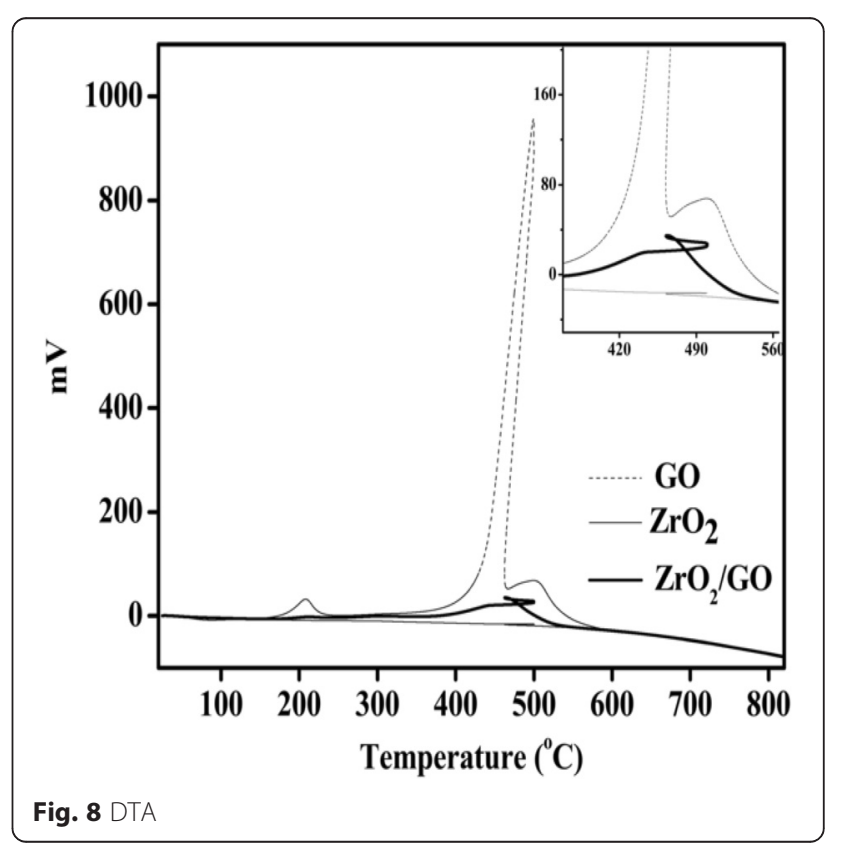




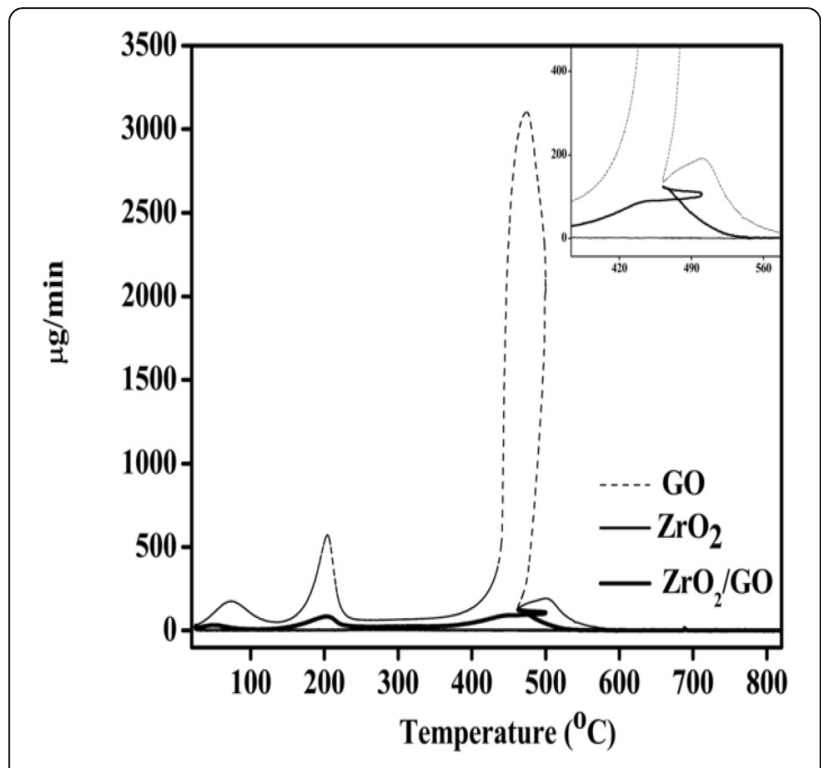

Fig. 9 DTG

range of 152 to $200{ }^{\circ} \mathrm{C}$ leaving weight residue $96.04 \%$. In comparison to $\mathrm{GO}$, such range of decomposition was shifted to lower temperature. This may be due to the formation of multiphase system that has reduced the thermal stability of NC over GO. During this temperature change, the $\mathrm{NC}$ was decomposed at $84 \mu \mathrm{J} / \mathrm{min}$ at $197^{\circ} \mathrm{C}$. Increase in temperature from $200{ }^{\circ} \mathrm{C}$ has induced a steep weight loss up to $400{ }^{\circ} \mathrm{C}$ leaving the weight residue $90.97 \%$ at $400{ }^{\circ} \mathrm{C}$; further increase in temperature to $500{ }^{\circ} \mathrm{C}$ leaving weight residue $83.74 \%$ was associated with a DTA signal of $34.9 \mu \mathrm{V}$ at $461{ }^{\circ} \mathrm{C}$ with heat of decomposition $1.71 \mathrm{~J} /$ $\mathrm{mg}$. This was supported with a DTG at $458^{\circ} \mathrm{C}$ with rate of decomposition $125 \mu \mathrm{g} / \mathrm{min}$; beyond $500{ }^{\circ} \mathrm{C}$, no remarkable weight was appeared in the NC. At $817^{\circ} \mathrm{C}$, the decomposition of $\mathrm{NC}$ was terminated leaving weight residue $83.07 \%$.

\section{Electrochemical characterization}

The electrochemical activity of the Zirconium oxidegraphene oxide nanocomposites was studied by measuring cyclic voltammograms (CV) and galvanostatic chargedischarge cycles of these nanomaterials. Full range CV of all the samples were scanned on Iviumstat electrochemical work station (Ivium technologies, Netherlands) at current compliance $10 \mathrm{~mA}$ and ranges of voltage compliance 0.0 to $-1.5 \mathrm{~V}$, at scan rate $0.05-0.15 \mathrm{~V} / \mathrm{s}$ using a conventional three-electrode cell assembly with reference to $\mathrm{Ag} / \mathrm{AgCl}$ electrode; Pt foil with $1 \mathrm{~cm}^{2}$ area was used as counter electrode and commercially available SS electrode as a working electrode. 1.0 M KOH solution was used as electrolyte in whole experiment.

All the electroactive material show I/V compliance in one anodic and one cathodic step; redox transitions between a semi-conducting state and a conducting state are responsible for cathodic and anodic peaks. With scan rate, all such I/V compliances were found to consist of increasing peak current and a shift in the voltage to higher values. The peak potential shift in $\mathrm{CV}$ is probably due to slow ion diffusion or interfacial charge transfer processes. In a $\mathrm{CV}$, the higher the redox peak, the greater is the electrochemical reaction activity (Mudila et al. 2014). CV curves of all the electrodes clearly show faradaic redox reactions, which exhibits anodic peaks associated with oxidation of material, and a cathodic peak corresponding to reduction (Figs. 10, 11, and 12). Among the three, NC-III had the greatest redox activity while the redox activity is the least for $\mathrm{ZrO}_{2}$.

\section{Supercapacitive characterization}

The supercapacitive studies of electroactive materials viz. $\mathrm{GO}, \mathrm{ZrO}_{2}$, and $\mathrm{NCs}$ were recorded at the common scan rate ranging $0.001-0.15 \mathrm{~V} / \mathrm{s}$, at -0.2 to 0.2 potential range (Table 2). The $\mathrm{CV}$ curves were found to be close to rectangular at the applied scan rates which indicate an excellent capacitive behavior and a low contact resistance in the as-prepared supercapacitor. Two mechanisms are responsible for the specific capacitance of metal oxide electrode: the surface adsorption/desorption and the intercalation/deintercalation of alkali metal ions (Lee et al. 2010). The calculations based on I/V characteristics reveal very low $\mathrm{C}_{\mathrm{S}}$ ranging 17.13 to $2.82 \mathrm{~F} / \mathrm{g}$ for $\mathrm{ZrO}_{2}$ (Fig. 13) (Kim et al. 2009).

Graphene oxide is known to comprise of well capacity and a potential material to store energy (Reta et al. 2009) (Fig. 14). At the above said potential range and scan rates, GO provides specific capacitance as high as

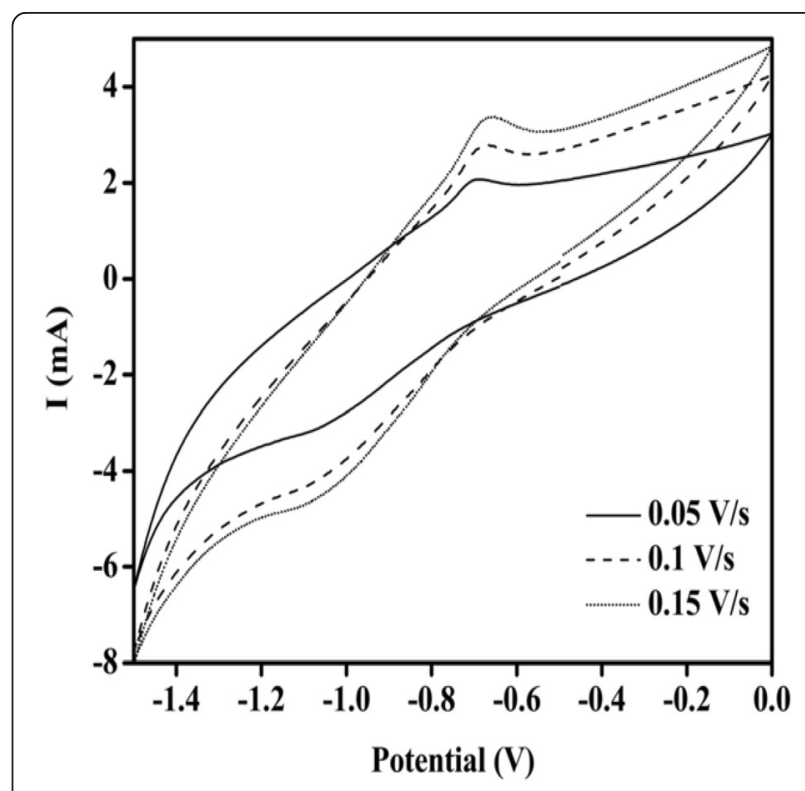

Fig. $10 \mathrm{CV}$ of GO showing anodic and cathodic peaks 


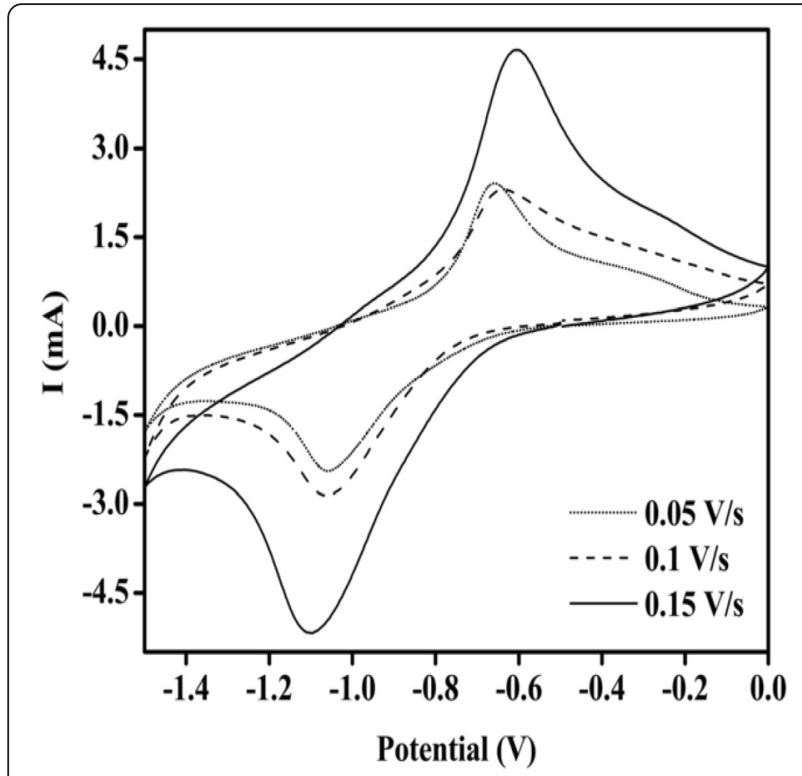

Fig. $11 \mathrm{CV}$ of $\mathrm{ZrO} 2$ showing anodic and cathodic peaks

161.62 F/g. Specific capacitance (Cs) of the active materials was calculated from the voltammetric charges by the $\mathrm{CV}$ curve, by means of relation:

$$
C s(F / g)=\frac{\mathrm{qa}+|\mathrm{qc}|}{2 m \Delta V}
$$

where "qa" and "qc" are the voltammetric charges on anodic and cathodic scans, in the capacitive potential region $(\Delta \mathrm{V})$, and " $\mathrm{m}$ " being the mass of active material. This comparative account reveals higher $\mathrm{C}_{S}$ of GO over $\mathrm{ZrO}_{2}$ (Fig. 15) which prompted to investigate the effect

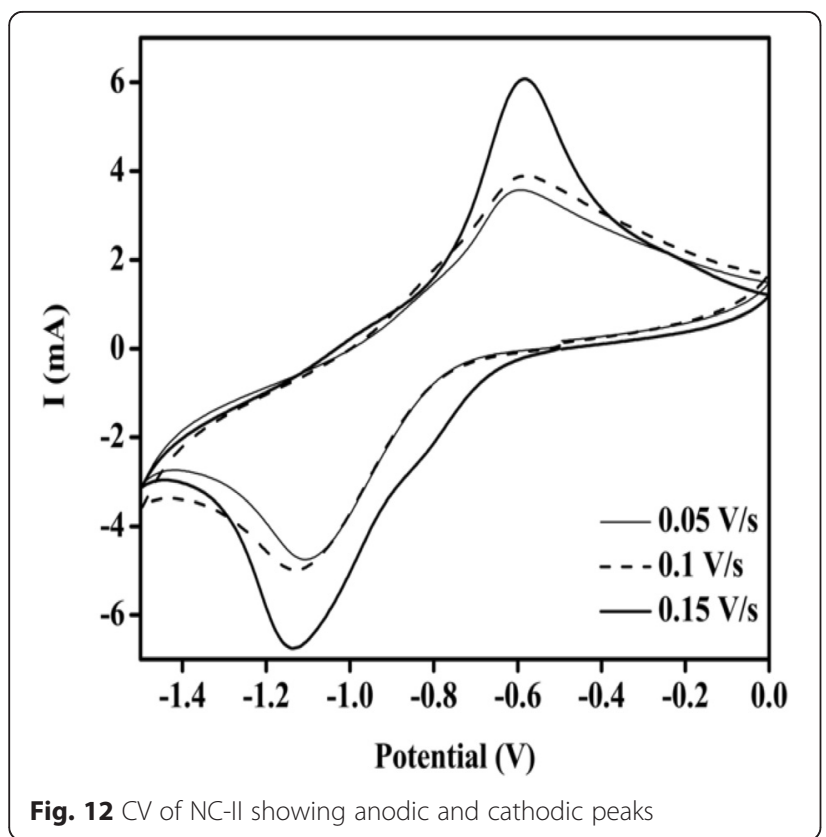

Table 2 Comparative oxidative and reductive potential of materials at varying scan rates

\begin{tabular}{clllr}
\hline Scan rate $(V / s)$ & $i_{a}(m A)$ & $E_{a}(V)$ & $i_{c}(m A)$ & $E_{c}(V)$ \\
\hline & & $G O$ & & \\
0.05 & 2.076 & -6.85 & -3.162 & 1.065 \\
0.10 & 2.778 & -6.75 & -4.224 & 1.070 \\
0.15 & 3.357 & -6.50 & -4.531 & 1.080 \\
& & $\mathrm{ZrO}_{2}$ & & \\
0.05 & 1.866 & -6.790 & -1.940 & -1.040 \\
0.10 & 2.274 & -6.510 & -2.395 & -1.057 \\
0.15 & 3.262 & -6.310 & -3.851 & -1.061 \\
& & $\mathrm{NC}-\|$ & & \\
0.05 & 3.371 & -6.810 & -5.088 & -1.065 \\
0.10 & 4.968 & -6.540 & -6.961 & -1.097 \\
0.15 & 5.972 & -6.250 & -8.286 & -1.109 \\
\hline
\end{tabular}

of $\mathrm{GO}$ concentration on the $\mathrm{C}_{\mathrm{S}}$ of $\mathrm{ZrO}_{2}$ in the respective NCs.

The capacitance of the $\mathrm{ZrO}_{2} / \mathrm{GO}$ nanocomposites was compared to those of pristine GO. The well-dispersed nanoscale $\mathrm{ZrO}_{2}$ particles on $\mathrm{GO}$ not only effectively inhibited agglomeration of GO, which resulted in a high capacitance, but also increased the electrochemical active surface areas of $\mathrm{ZrO}_{2}$. The enhanced capacitance for the composite electrodes was related to the combined effect of the pseudocapacitance of $\mathrm{ZrO}_{2}$ and GO. The area of the $\mathrm{CV}$ is directly proportional to the electrochemical capacitance of the electrode material. Thus, it is visually apparent from Figs. 14 and 16 that the electrochemical capacitance of $\mathrm{NC}-\mathrm{II}$ is much higher than that of all other electrode materials which is confirmed

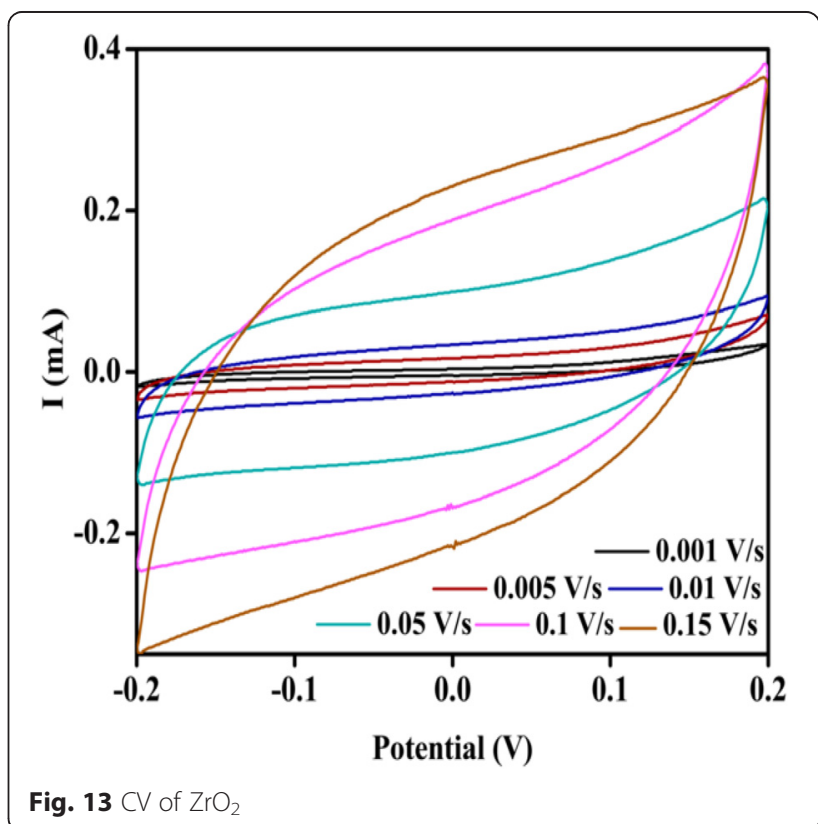




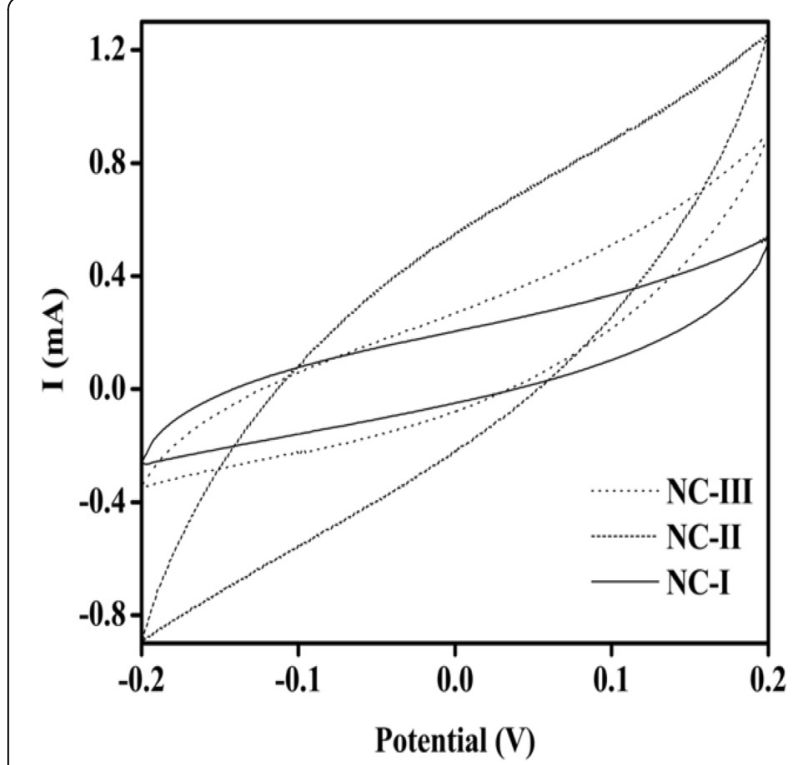

Fig. 14 CV of NCS

by the values of specific capacitance. It was also a matter of concern that NC-II $(17.75 \mathrm{~F} / \mathrm{g})$ had shown comparable specific capacitance to $\mathrm{ZrO}_{2} /$ graphene nanocomposite (Liu et al. 2013) which was found to be $10.2 \mathrm{~F} / \mathrm{g}$ at $0.05 \mathrm{~V} / \mathrm{s}$.

With various concentrations of $\mathrm{ZrO}_{2}$ and GO, under identical I/V compliance, NC-I corresponds to the $\mathrm{C}_{\mathrm{S}}$ ranging 4.40 to $175.37 \mathrm{~F} / \mathrm{g}$ at proposed scan rates, NCIII shows $C_{S}$ ranges from 4.58 to $250.41 \mathrm{~F} / \mathrm{g}$, while for $\mathrm{NC}-\mathrm{II}$, it was reported to be ranging from 10.58 to $299.26 \mathrm{~F} / \mathrm{g}$. All such NCs metal oxide and GO display stable I/V compliance till 1000 cycles (Fig. 18). At a high

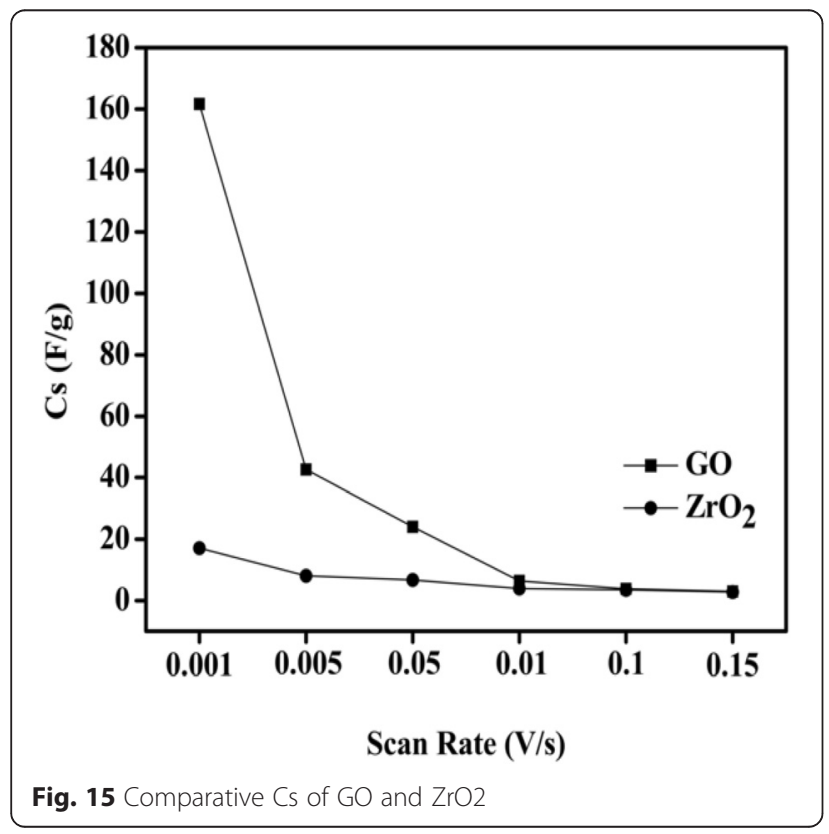

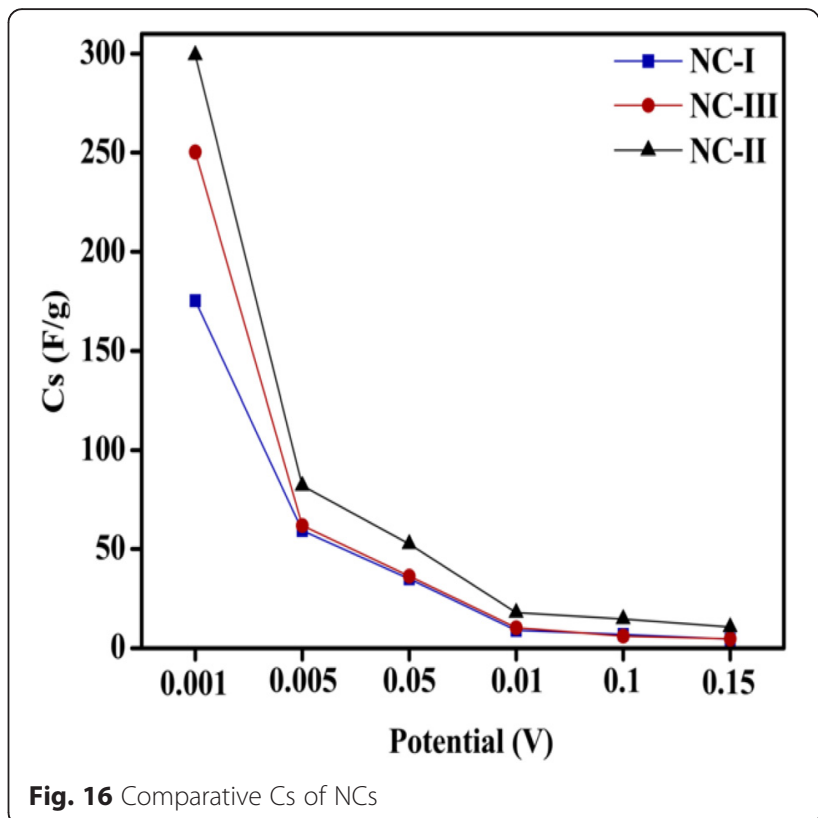

scan rate, diffusion of electrolyte ions was limited due to the time constraint and only the outer active surface was utilized for charge storage; thus, specific capacitance decreased with increase in scan rate from 0.001 to $0.15 \mathrm{~V} / \mathrm{s}$. (Fig. 16). The present results of electrochemical measurement clearly demonstrate that the increase in concentration of graphene oxide leads to the increase in the specific capacitance to a limit beyond which the decrease in specific capacitance of NCs was encountered. This strongly suggests that the high content of graphene oxide is not advantageous for improving the electrode performance of the NCs.

The specific energy density $(E)$ and maximum specific power density $(P)$ of NCs were found to be high and were calculated respectively through the following relations (Guo and Ding 2004):

$$
\begin{aligned}
& E(\mathrm{Wh} / \mathrm{kg})=\frac{\mathrm{Cs}(\Delta \mathrm{V})^{2}}{2} \\
& P(W / \mathrm{kg})=\frac{E}{t}
\end{aligned}
$$

where "Cs" is the specific capacitance, $\Delta \mathrm{V}$ is the applied initial voltage, and " $\mathrm{t}$ " is the corresponding discharge time in hour. The NC-II was evaluated as the representative of $\mathrm{ZrO}_{2} / \mathrm{GO}$ nanocomposites for further studies and the maximum energy density of $0.38 \mathrm{Wh} / \mathrm{Kg}$ and $6.6 \mathrm{Wh} / \mathrm{Kg}$ for $\mathrm{ZrO}_{2}$ and NC-II, while corresponding power density of 13.68 and $59.40 \mathrm{~W} / \mathrm{kg}$ was accounted for $\mathrm{ZrO}_{2}$ and NC-II, respectively.

Figure 17 shows systematic reversible chargingdischarging curves of $\mathrm{ZrO}_{2}$ and corresponding NCs recorded in the voltage range from -0.2 to $0.2 \mathrm{~V}$ at an 


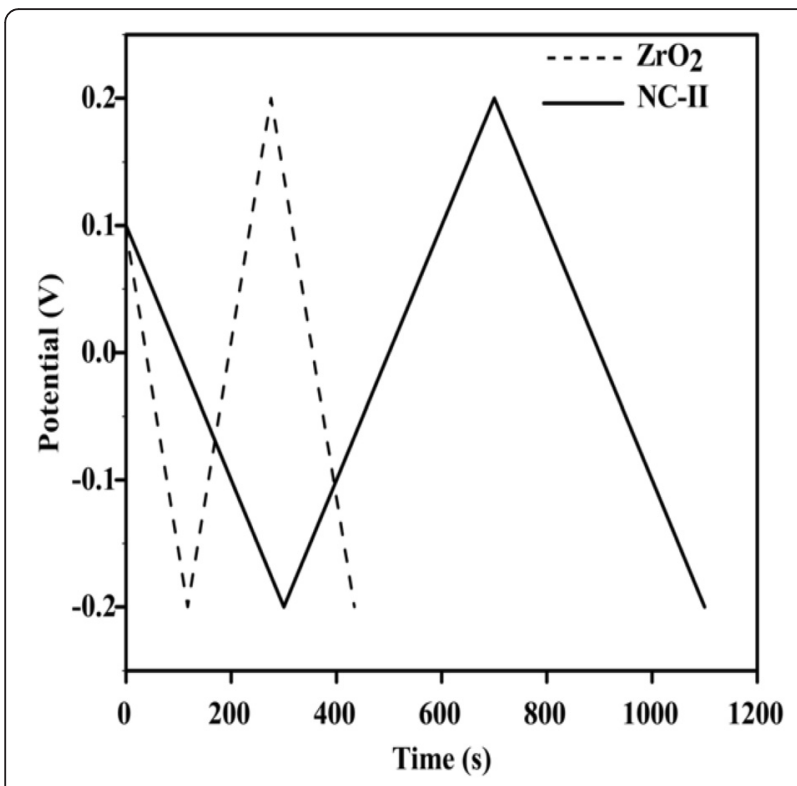

Fig. 17 Charge-discharge curves

applied current density of $10 \mathrm{~mA} / \mathrm{cm}^{2}$ without any apparent deviation in each cycle. These charge/discharge curves are almost linear in the full range of potential with constant slopes, depicting perfect electrocapacitive behavior. This suggests good electrochemical stability for the $\mathrm{NC}$ electrodes.

A rapid fall up to 50 cycles was observed after which the capacitance remained constant throughout the cycling period for 1000 cycles at a $0.1 \mathrm{~V} / \mathrm{s}$ (Fig. 18); this indicates the excellent cyclic stability of the nanocomposites for supercapacitor applications. Thus, introduction of GO had afforded NCs to attain electrochemical activity with

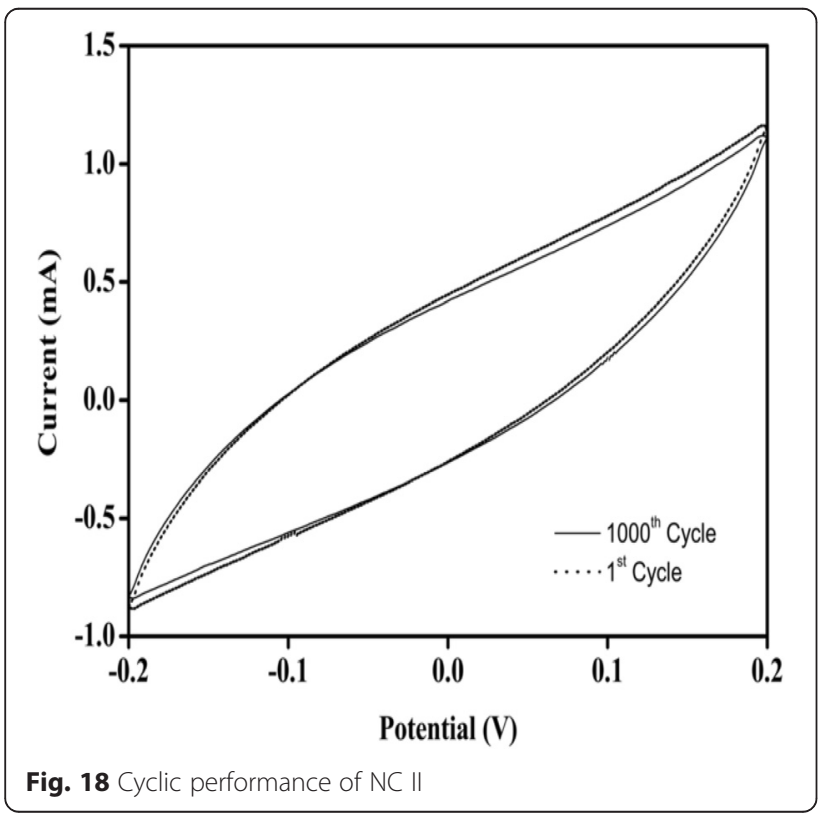

higher level specific capacitance and excellent power performance. This result implies that the $\mathrm{ZrO}_{2} / \mathrm{GO}$ nanocomposite could be considered as a promising material in solving problems for electrochemical supercapacitors without losing its performance and can be employed as the electric energy storage device for the hybrid vehicles and new generation electronic devices.

\section{Conclusions}

In summary, the fabricated $\mathrm{ZrO}_{2} / \mathrm{GO}$ nanocomposites present efficient high-power material for supercapacitive studies. These materials were observed to have good thermal stability, specific capacitance, and cycleability as confirm by TG-DTA-DTG and CV studies, respectively. The electrochemical outcome clearly demonstrates that the increase of graphene oxide after a certain limit (here $\mathrm{ZrO} 2$ : GO, 1:2) leads to the decline of the specific capacitance of nanocomposite. This strongly advocates that the high content of graphene oxide is not advantageous for enhancing the electrode performance of the nanocomposite. The remarkable performance of $\mathrm{ZrO}_{2} / \mathrm{GO}$ nanocomposite could be credited to the nanosize and high surface area of $\mathrm{ZrO}_{2}$ particles along with the good electronic conductivity of GO. Both factors can contribute to the enhanced charge-transfer-reaction pseudocapacitance of the NCs, which is based on rapid and reversible redox reactions at the surface of electrode. FT-IR SEM studies were performed to confirm the intermixing of reactant material, while XRD confirms the nanosized materials with layered matrix.

\section{Abbreviations}

GO: graphene oxide; hr: hour; mg: milligram; mL: milliliter; NCs: nanocomposites; PSO: polysulphone; SPS: sulphonated polysulphone; SS: stainless steel; TEAB: tetraethyl ammonium bromide; $\mathrm{ZrO}_{2}$ : zriconium oxide; $\mu \mathrm{L}$ : microlitre.

\section{Competing interests}

The authors declare that they have no competing interests.

\section{Authors' contributions}

$H M, S R$ and MGHZ conceived of the original idea and design of the work. $\mathrm{HM}$ and SR performed the preparation of material, fabrication of electrode and other electrochemical studies. HM, SR and MGHZ performed the data interpretation and manuscript writing. All authors had read and approved the final manuscript.

\section{Author details}

'Department of Chemistry, Lovely Professional University, Phagwara, Punjab 144411, India. ${ }^{2}$ Department of Chemistry, G. B. Pant University of Agriculture \& Technology, Pantnagar, Uttarakhand 263145, India.

Received: 20 September 2015 Accepted: 12 January 2016 Published online: 22 January 2016

\section{References}

Chang S, Doong R. $\mathrm{ZrO}_{2}$ thin films with controllable morphology and thickness by spin-coated sol-gel method. Thin Solid Films. 2005;489:17-22.

Chen CM, Zhang Q, Huang JQ, Zhang W, Zhao XC, Huang CH, et al. Chemically derived graphene-metal oxide hybrids as electrodes for electrochemical 
energy storage: pre-graphenization or post-graphenization. J Mater Chem. 2012:22:13947-55.

Cheng Q, Tang J, Ma J, Zhang H, Shinya N, Qin LC. Graphene and nanostructured MnO2 composite electrodes for supercapacitors. Carbon. 2011;49:2917-25.

Graves Jr JL. A grain of salt: metallic and metallic oxide nanoparticles as the new antimicrobials. JSM Nanotechnol Nanomed. 2014;2(2):1026-30.

Guo X, Ding Y. Grain boundary space charge effect in zirconia experimental evidence. J Electrochem Soc. 2004;151(1):J1-7.

Guo D, Qiu X, Zhu W, Chen L. Synthesis of sulfated $\mathrm{ZrO}_{2} /$ MWCNT composites as new supports of Pt catalysts for direct methanol fuel cell application. Appl Catal B. 2009;89(3- 4):597-601.

He YN, Zhu JQ, Zhang T, Wang X, Tang D. Effects of composition on the structure and capacitive properties of $\mathrm{Ti} /(\mathrm{ZrO} 2) x(\mathrm{RuO} 2) 1-x$ electrodes. Chin J Struct Chem. 2013;32(2):231-5.

Javey A, Kim H, Brink M, Wang Q, Ural A, Guo J, et al. High-k dielectrics for advanced carbon-nanotube transistors and logic gates. Nature. 2002;1:241-6.

Kim SR, Parvez MK, Chhowalla M. UV-reduction of graphene oxide and its application as an interfacial layer to reduce the back-transport reactions in dye-sensitized solar cells. Chem Phys Lett. 2009;483:124-7.

Lee S, Kang B, Lee S, Jeong H, Song IAC. Optical, electrical, and structural properties of ultrathin zirconium-oxide films. J Korean Phys Soc. 2010;57(6):1811-5.

Lee YR, Song MS, Lee KM, Kim IY, Hwang SJ. Synthesis and electrochemical characterization of reduced graphene oxide-manganese oxide nanocomposites. J Electrochem Sci Technol. 2011;2(1):1-7.

Liu J, Meng X, Hu Y, Geng D, Banis MN, Cai M, et al. Controlled synthesis of zirconium oxide on graphene nanosheets by atomic layer deposition and its growth mechanism. Carbon. 2013;52:74-82.

Lu J, Zang JB, Shan SX, Huang H, Wang YH. Synthesis and characterization of core-shell structural MWNT-zirconia nanocomposites. Nano Lett. 2008;8(11):4070-4.

Mai $Y$, Zhang F, Feng $X$. Polymer-directed synthesis of metal oxidecontaining nanomaterials for electrochemical energy storage. Nanoscale. 2014;6:106-21.

Marcos FG, Rodriguez JA. Metal oxide nanoparticles. USA: Brookhaven National Laboratory; 2007. BNL-79479-2007-BC.

Mudila H, Rana S, Zaidi MGH, Alam S. Polyindole/graphene oxide nanocomposites: the novel material for electrochemical energy storage. Fullerenes Nanotubes Carbon Nanostruct. 2014. doi:10.1080/1536383X. 2013.787604

Mugniery X, Chafk T, Primet M, Bianchi D. Characterization of the sites involved in the adsorption of $\mathrm{CO}$ on $\mathrm{ZrO} 2$ and $\mathrm{ZnO} / \mathrm{ZrO} 2$ methanol synthesis aerogel catalysts. Catal Today. 1999;52:15-22.

Pham VH, Cuong TV, Hur SH, Oh E, Kim EJ, Shin EW, et al. Chemical functionalization of graphene sheets by solvothermal reduction of suspension of graphene oxide in N-methyl-2-pyrrolidone. J Mater Chem. 2011;21:3371-7.

Pouretedal HR, Hosseini M. Bleaching kinetic and mechanism study of Congo red catalyzed by $\mathrm{ZrO} 2$ nanoparticles prepared by using a simple precipitation method. Acta Chim Slov. 2010;57:415-23.

Reta JL, Garc'ia R, Sandoval G, Rivera JL. Preparation of zirconium oxides modified with borate ions tested in catalytic dehydration of ethanol. Rev Mex Defisicas. 2009;55(1):98-101.

Sahu HR, Rao GR. Characterization of combustion synthesized zirconia powder by UV-vis, IR and other techniques. Bull Mater Sci. 2000;23(5):349-54.

Shan Y, Gao L. Synthesis and characterization of phase controllable ZrO2-carbon nanotube nanocomposites. Nanotechnology. 2005;16:625-30.

Some S, Kim Y, Yoon Y, Yoo HJ, Lee S, Park Y, et al. High-quality reduced graphene oxide by a dual-function chemical reduction and healing process. Sci Rep. 2013;3:1929. doi:10.1038/srep01929.

Song H, Qiu X, Li F. Promotion of carbon nanotube supported Pt catalyst for methanol and ethanol electrooxidation by $\mathrm{ZrO} 2$ in acidic media. Appl Catal A. 2009:364:1-7.

Stoller MD, Park S, Zhu Y, An J, Ruoff RS. Graphene-based ultracapacitors. Nano Lett. 2008;8(10):3498-502. doi:10.1021/nl802558y.

Suchorski Y, Wrobel R, Becker S, Opalinska A, Narkiewicz U, Podsiadly M, et al. Surface chemistry of zirconia nanopowders doped with Pr2O3: an XPS study. Acta Phys Pol A. 2008;114:125-33.

Tian J, Liu S, Zhang Y, Li H, Wang L, Luo Y, et al. Environmentally friendly, onepot synthesis of Ag nanoparticle-decorated reduced graphene oxide composites and their application to photocurrent generation. Inorg Chem. 2012;51(8):4742-6.
Tuller HL. Ionic conduction in nanocrystalline materials. Solid State Ion. 2000;131:143-57.

Vilian ATE, Chen SM, Ali MA, Al-Hemaid FMA. Direct electrochemistry of glucose oxidase immobilized on $\mathrm{ZrO}_{2}$ nanoparticles-decorated reduced graphene oxide sheets for a glucose biosensor. RSC Adv. 2014;4:30358-67.

Wang D, Kou R, Choi D, Yang Z, Nie Z, Li J, et al. Ternary self-assembly of ordered metal oxide-graphene nanocomposites for electrochemical energy storage. ACS Nano. 2010;4(3):1587-95.

Wu ZS, Zhou G, Yin LC, Ren W, Li F, Cheng HM. Graphene/metal oxide composite electrode materials for energy storage. Nano Energy. 2012;1:107-31.

Yang $H$, Jiang J, Zhou W, Lai L, Xi L, Lam YM, et al. Influences of graphene oxide support on the electrochemical performances of graphene oxide- $\mathrm{MnO}_{2}$ nanocomposites. Nanoscale Res Lett. 2011;6:531-8.

Ye KH, Liu ZQ, Xu CW, Li N, Chen YB, Su YZ. MnO2/reduced graphene oxide composite as high-performance electrode for flexible supercapacitors. Inorg Chem Commun. 2013;30:1-4.

Yee KJ, Kim JH, Jung MH, HongB H, Kong KJ. Ultrafast modulation of optical transitions in monolayer and multilayer graphene. Carbon. 2011;49:4781.

Yoo JJ, Balakrishnan K, Huang J, Meunier V, Sumpter BG, Srivastava A, et al. Ultrathin planar graphene supercapacitors. Nano Letts. 2011;11:1423-7.

Zhao H, Pan L, Xing S, Luo J, Xu J. Vanadium oxides reduced graphene oxide composite for lithium-ion batteries and supercapacitors with improved electrochemical performance. J Power Sources. 2013;222:21-31.

\section{Submit your manuscript to a SpringerOpen ${ }^{\circ}$ journal and benefit from:}

- Convenient online submission

- Rigorous peer review

- Immediate publication on acceptance

- Open access: articles freely available online

- High visibility within the field

- Retaining the copyright to your article

Submit your next manuscript at springeropen.com 